\title{
Respon Pemberian Pupuk Mikrobat Dengan Berat Umbi Berbeda Terhadap Pertumbuhan dan Produksi Tanaman Bawang Merah (Allium ascalonicum L)
}

\author{
Harli A. Karim ${ }^{1}$, Abd. Jamal ${ }^{2}$, Tri Sutrisno ${ }^{3}$ \\ Program Studi Agroteknologi, Fakultas Pertanian, Universitas Al Asyariah Mandar \\ Email : harlipertanian@gmail.com
}

\begin{abstract}
Abstrak
Bawang merah merupakan komoditi hortikultura yang tergolong sayuran rempah. Sayuran rempah ini banyak dibutuhkan terutama sebagai pelengkap bumbu masakan guna menambah cita rasa dan kenikmatan masakan. Selain sebagai bumbu masak, bawang merah dapat juga digunakan sebagai obat tradisional yang bermanfaat untuk kesehatan. Selain berfungsi sebagai bumbu dapur dan penyedap masakan, bawang merah juga bermanfaat bagi kesehatan diantaranya untuk penyembuhan sembelit, mengontrol tekanan darah, menurunkan kolesterol, menurunkan resiko diabetes, mencegah pertumbuhan sel kanker dan mengurangi resiko gangguan hati. Metode yang digunakan dalam penelitian ini yaitu Rancangan Acak Kelompok (RAK) dengan pola faktorial terdiri dari 2 faktor. Faktor pertama yaitu pemberian Mikrobat dengan 3 taraf yaitu: 0, 10 dan $20 \mathrm{ml} /$ liter air; Faktor kedua adalah berat umbi bawang merah terdiri dari 3 taraf yaitu: 6,8 dan 10 gram/umbi. Hasil penelitian menunjukkan bahwa pemberian pupuk Mikrobat dengan dosis 20 lm/liter air memberikan pengaruh baik terhadap parameter panjang daun, jumlah daun, jumlah anakan, berat segar dan berat kering tanaman bawang merah. Penanaman berat umbi 10 gram berpengaruh lebih baik pada jumlah daun, jumlah anakan, berat segar dan berat kering tanaman bawang merah. Interaksi antara pupuk Mikrobat dengan dosis $20 \mathrm{~lm} /$ liter air dengan berat umbi \pm 6 gram memberikan pengaruh baik pada parameter panjang daun pada umur 28, 42 dan 56 HST dan juga jumlah daun pada umur 14 dan 42 HST.
\end{abstract}

Keywords : pupuk, mikrobat, berat umbi, bawang merah

\section{Pendahuluan}

Bawang merah (Allium ascalonicum L.) merupakan komoditi hortikultura yang tergolong sayuran rempah. Sayuran rempah ini banyak dibutuhkan terutama sebagai pelengkap bumbu masakan guna menambah cita rasa dan kenikmatan masakan. Selain sebagai bumbu masak, bawang merah dapat juga digunakan sebagai obat tradisional yang bermanfaat untuk kesehatan.

Selain berfungsi sebagai bumbu dapur dan penyedap masakan, bawang merah juga bermanfaat bagi kesehatan diantaranya untuk penyembuhan sembelit, mengontrol tekanan darah, menurunkan kolesterol, menurunkan resiko diabetes, mencegah pertumbuhan sel kanker dan mengurangi resiko gangguan hati (Wibowo, 2010).

Bawang merah tergolong komoditi yang mempunyai nilai jual tinggi dipasaran. Pada saat ini sentra produksi dan budi daya bawang merah perlu ditingkatkan mengingat permintaan konsumen dari waktu ke waktu terus meningkat sejalan dengan pertambahan jumlah penduduk dan peningkatan daya belinya. Mengingat kebutuhan terhadap bawang merah yang kian terus meningkat maka pengusahanya memberikan prospek yang cerah.
Produksi bawang merah tahun 2015 sebesar 1,234 juta ton. Dibanding dengan tahun 2014, produksi meningkat sebesar 223.33 ribu ton (22.0\%) (BPS, 2015). Konsumsi bawang merah di Indonesia $4.56 \mathrm{~kg}$ kapita pertahun atau $0,38 \mathrm{~kg}$ kapita perbulan dan mengalami kenaikan sebesar $10 \%$ hingga $20 \%$ menjelang hari-hari besar keagamaan. Perkiraan kebutuhan bawang merah tahun 2019 mencapai 1,195,235 ton yang terbagi kebutuhan konsumsi 952,335 ton, kebutuhan benih 102,900 ton, kebutuhan industri 40,000 ton dan kebutuhan ekspor 100,000 ton. Produktivitas bawang merah di Indonesia masih tergolong rendah dengan kisaran 9 ton ha-1, sedangkan potensinya dapat mencapai 17 ton ha-1 (Ciptady, 2015).

Rendahnya produksi tersebut disebabkan budidaya yang belum sempurna, pemupukan yang belum dilakukan secara intensif. Serta kondisi lingkungan yang tidak menguntungkan. Untuk meningkatkan kesuburan tanah dapat dilakukan dengan pemupukan. Pada umumnya para petani bawang merah sering mengunakan pupuk anorganik secara berlebihan sebagai solusi untuk meningkatkan hasil produksi bawang merah. Padahal rendahnya produktifitas bawang merah disebabkan oleh sistem budidaya yang belum maksimal dan penggunaan pupuk anorganik yang berlebihan sehingga lama kelamaan akan berdampak pada kesuburan tanah yang 
dapat mengakibatkan produktifitas tanah menurun (Samad, 2010).

Salah satu upaya yang bisa dilakukan untuk mengatasi permasalahan tersebut adalah penggunaan pupuk Mikrobat yang bermanfaat memperkawa hara, dan memperbaiki sifat fisik, kimia dan biologi tanah. Beberapa tahun terakhir ini, penggunaan pupuk Mikroba pada tanaman sayuran juga telah dilaksanakan dan tampaknya memberikan prospek yang cukup cerah untuk pertanian masa mendatang. Hasil-hasil penelitian pupuk Mikroba menunjukkan bahwa penggunaan pupuk Mikroba dalam bentuk cair yang mampu diaplikasikan langsung ke media persemaian dan zone perakaran pada tanaman bawang merah, tomat, kubis, dan cabai memberikan hasil yang lebih baik.

Pupuk Mikrobat merupakan jenis pupuk yang tidak mengandung unsur hara seperti N, P, dan K. Pupuk Mikrobat mengandung mikrooganisme yang memiliki peranan positif bagi tanaman yaitu membantu menyediakan hara yang dibutuhkan tanaman. Kelompok mikroba yang digunakan dalam pupuk Mikrobat adalah mikroba yang mampu menambat unsur $\mathrm{N}$ dari udara dan mikroba yang dapat melarutkan unsur $\mathrm{P}$ dan $\mathrm{K}$ dalam keadaan yang tidak dapat diserap oleh tannaman menjadi dapat diserap oleh tanaman. Kelompok mikroorganisme tersebut antara lain seperti. Bakteri penambat N, bakteri palarut $\mathrm{P}$, bakteri penghasil ZPT, bakteri pengedali hayati, bakteri pendegradasi selolusa (Andriawan, 2010).

Hasil penelitian yang dilakukan (Taufiq Bachtiar dkk., 2017) dapat diketahui bahwa pupuk Mikroba pada tanaman jagung dapat meningkatkan $\mathrm{N}$ total sebesar $22.93 \%$, serapan P sebesar $55.26 \%$, tinggi tanaman sebesar $14.62 \%$, berat kering tanaman sebesar $122.58 \%$, dan berat kering tongkol sebesar $83.52 \%$ bila dibandingkan dengan kontrol. Sedangkan (Melissa Syamsiah.,dkk 2013) dalam hasil penelitiannya pemberian pupuk Mikrobat pada tanaman kedelai berpengaruh nyata terhadap semua perameter pengamatan panjang akar, jumlah bintil akar, dan berat bintil akar.

Sementara itu, penyediaan benih bawang merah berupa umbi masih terbatas, karena perbanyakannya yang masih rendah dan penggunaan ukuran benih yang besar. Pada saat harga benih mahal, ukuran benih yang besar dapat meningkatkan biaya produksi. Hal ini sejalan dengan pemikiran bahwa semakin besar bobot umbi bawang yang ditanam dapat memberikan produksi lebih tinggi dibandingkan dengan menggunakan benih dengan bobot ukuran lebih kecil (Sumarni dan Hidayat, 2009).

Umbi besar dapat menyediakan cadangan makanan yang cukup untuk menunjang pertumbuhan dan perkembangan di lapangan. Umbi benih berukuran besar tumbuh lebih baik dan menghasilkan daun-daun lebih panjang, luas daun lebih besar, sehingga dihasilkan jumlah umbi per tanaman dan total hasil yang tinggi. Namun, penggunaan umbi benih yang berukuran besar berkaitan erat dengan total bobot benih yang diperlukan dan sekaligus memengaruhi biaya produksi untuk benih, sehingga menjadi lebih tinggi (Sutono, 2010).
Hasil penelitian yang dilakukan (Azmi, dkk., 2011) ukuran umbi memberikan pengaruh yang nyata pada parameter yang diamati. Jumlah umbi terbanyak dihasilkan oleh varietas Bima, sedangkan ukuran diameter umbi terbesar dihasilkan oleh varietas Maja. Ukuran umbi sedang dan besar memberikan hasil yang tidak berbeda nyata. Penggunaan umbi benih bawang merah berukuran sedang (Bima: 1,39-1,77 cm, Maja: 1,46-1,97 cm, Sumenep: 1,27-1,63 cm) dapat digunakan untuk produksi bawang merah yang dapat menekan biaya produksi untuk benih sekitar 33-40\%.

Sehubungan dengan hal tersebut diatas maka perlu dilakukan penelitian dengan judul "Respon Pemberian Pupuk Mikrobat dengan Berat Umbi Berbeda Terhadap Pertumbuhan dan Produksi Tanaman Bawang Merah".

\section{Bahan Dan Metode}

Penelitian ini dilaksanakan di Lahan Fakultas Pertanian Universitas Al-Asy'ariah Mandar, Kelurahan Madatte, Kecamatan Polewali, Kabupaten Polewali Mandar. Berlangsung dari bulan Agustus sampai bulan Oktober 2018. Bahan yang digunakan dalam penelitian ini adalah umbi bawang merah varietas bima, Mikrobat, polybag ukuran 30 x $40 \mathrm{~cm}$. Alat yang digunakan dalam penelitian ini adalah alat tulis menulis, timbangan digital, cangkul, ember, spoit, handsprayer, mistar/meter, camera, label.

Metode yang digunakan dalam penelitian ini adalah Rancangan Acak Kelompok (RAK) Dengan pola faktorial terdiri dari 2 faktor. Faktor pertama yaitu pemberian Mikrobat dengan 3 taraf yaitu: $\mathrm{C} 0$ : 0 (kontrol), C1 :10 ml/liter air dan C2: $20 \mathrm{ml} /$ liter air. Faktor kedua adalah berat umbi bawang merah terdiri dari 3 taraf yaitu:B1: \pm 6 gram/umbi, B : \pm 8 gram/umbi, B3: \pm 10 gram/umbi. Sehingga dengan demikian terdapat 9 (sembilan) kombinasi perlakuan yaitu: dimana setiap perlakuan diulang sebanyak 3 kali sehingga terdapat 27 unit penelitian.

\section{Hasil Dan Pembahasan}

Data pengamatan panjang daun. Sidik ragam menunjukkan bahwa pemberian pupuk Mikrobat (C) dengan berat umbi berbeda (B) memberikan pengaruh sangat nyata. Sedangkan interaksinya tidak berpengaruh nyata terhadap panjang daun.

Tabel 1. Rata-Rata Panjang Daun (cm) pada Pemberian Pupuk Mikrobat dengan Berat Umbi Berbeda terhadap Pertumbuhan dan Produksi Tanaman Bawang Merah pada umur 14 HST.

\begin{tabular}{cccccc}
\hline $\begin{array}{l}\text { Pupuk } \\
\text { Mikrobat }\end{array}$ & B1 & B2 & B3 & $\begin{array}{c}\text { Rata- } \\
\text { Rata }\end{array}$ & $\begin{array}{c}\text { BNT } \\
\text { Taraf } \\
\boldsymbol{\alpha} \mathbf{0 , 0 1}\end{array}$ \\
\cline { 2 - 4 } C0 & 10.67 & 9.83 & 10.17 & $10.22^{\mathrm{a}}$ & 0.67 \\
C1 & 12.83 & 12.17 & 11.33 & $12.11^{\mathrm{b}}$ & \\
\multicolumn{1}{c}{2} & 15.33 & 14.00 & 13.50 & $14.28^{\mathrm{c}}$ & \\
\hline Rata-Rata & $12.94^{\mathrm{b}}$ & $12.00^{\mathrm{a}}$ & $11.67^{\mathrm{a}}$ & & \\
\hline BNT Taraf & & & & & \\
$\boldsymbol{\alpha} \mathbf{0 , 0 1}$ & 0.67 & & & & \\
\hline
\end{tabular}


Keterangan : Angka-angka yang diikuti oleh huruf yang tidak sama berarti berbeda nyata pada BNT Taraf $\alpha 0,01$

Hasil Uji Beda Nyata Terkecil pada tara $\alpha 0,01$ pada Tabel 1. Memperlihatkan bahwa perlakuan pupuk Mikrobat dengan dosis $20 \mathrm{ml} /$ liter air (C2) berpengarauh lebih baik dan berbeda sangat nyata dibandingkan dengan perlakuan yang lain. Demikian juga dengan berat umbi \pm 6 gram (B1) memperlihatkan panjang daun terbaik dan berbeda sangat nyata dibandingkan dengan perlakuan yang lain.

Data hasil pengamatan panjang daun tanaman bawang merah diumur 28, 42 dan 56 HST. Sidik ragam menunjukkan bahwa pemberian pupuk Mikrobat (C) berpengaruh sagat nyata diumur 42 dan 56 HST sedangkan diumur 28 HST tidak berpengaruh nyata. Demikian juga dengan berat umbi yang berbeda (B) berpengaruh sagat nyata pada umur 42 dan 56 HST sedangkan diumur 28 HST tidak berpengaruh nyata. Sedangkan interaksinya memperlihatkan pegaruh sangat nyata diumur 56 HST namun tidak berbeda nyata pada umur 28 dan 42 HST

Tabel 2. Rata-Rata Panjang Daun $(\mathrm{cm})$ pada Pemberian Pupuk Mikrobat dengan Berat Umbi Berbeda Bawang Merah pada umur 28, 42 dan 56 HST.

\begin{tabular}{|c|c|c|c|}
\hline \multirow{2}{*}{ Perlakuan } & \multicolumn{3}{|c|}{ Panjang Daun (Cm) } \\
\hline & 28 HST & $42 \mathrm{HST}$ & $56 \mathrm{HST}$ \\
\hline C0B1 & $29,33^{\mathrm{a}}$ & $38,00^{\mathbf{a}}$ & $40,67^{\mathrm{a}}$ \\
\hline C0B2 & $28,67^{\mathrm{a}}$ & $36,83^{\mathrm{a}}$ & $39,67^{\mathrm{a}}$ \\
\hline C0B3 & $28,17^{\mathrm{a}}$ & $36,33^{\mathrm{a}}$ & $39,17^{\mathrm{a}}$ \\
\hline C1B1 & $20,17^{\mathrm{a}}$ & $39,33^{\mathbf{c}}$ & $41,83^{\mathrm{c}}$ \\
\hline C1B2 & $31,33^{\mathrm{a}}$ & $39,17^{\mathrm{a}}$ & $41,83^{\mathrm{c}}$ \\
\hline C1B3 & $30,67^{\mathrm{a}}$ & $39,00^{\mathrm{c}}$ & $41,83^{\mathrm{c}}$ \\
\hline C2B1 & $35,00^{b}$ & $40,50^{\mathrm{b}}$ & $43,17^{b}$ \\
\hline C2B2 & $32,33^{\mathrm{c}}$ & $39,17^{\mathbf{a}}$ & $41,83^{\mathrm{c}}$ \\
\hline \multirow{2}{*}{ C2B3 } & $25,50^{\mathrm{a}}$ & $37,67^{\mathrm{a}}$ & $40,33^{\mathrm{a}}$ \\
\hline & $3,80^{*}$ & $0,40^{*}$ & $0,33^{* *}$ \\
\hline BNT & \multicolumn{3}{|c|}{ Taraf $\alpha 0,05$ Taraf $\alpha 0,05$ Taraf $\alpha 0,01$} \\
\hline \multicolumn{4}{|c|}{$\begin{array}{l}\text { Keterangan : Angka-angka yang diikuti oleh huruf yang tidak sama } \\
\text { pada kolom menunjukkan berbeda sangat nyata pada } \\
\text { BNT Taraf } \alpha 0,01 \text { dan Taraf } \alpha 0,05 ; \text { tn: tidak nyata; * } \\
\text { nyata; } * * \text { : sangat nyata. }\end{array}$} \\
\hline
\end{tabular}

Hasil Uji Beda Nyata Terkecil pada taraf $\alpha 0,01$ dan taraf $\alpha 0,05$ pada Tabel 2. Memperlihatkan bahwa perlakuan pupuk Mikrobat dengan dosis $20 \mathrm{ml} /$ liter air dengan berat umbi \pm 6 gram (C2B1) memperlihatkan rata-rata panjang daun terbaik dan berbeda nyata dengan perlakuan lainnya pada umur 28 HST. Sedangkan pada umur 42 HST memperlihatkan bahwa perlakuan pupuk Mikrobat dengan dosis $20 \mathrm{ml} /$ liter air dengan berat umbi \pm 6 gram (C2B1) memperlihatkan rata-rata panjang daun terbaik dan berbeda nyata dengan perlakuan lainnya, dan juga pada umur 56 HST. Memperlihatkan bahwa perlakuan pupuk Mikrobat dengan dosis $20 \mathrm{ml} /$ liter air dengan berat umbi \pm 6 gram (C2B1) memperlihatkan rata-rata panjang daun terbaik dan berbeda nyata dengan perlakuan lainnya.

\section{Jumlah Daun}

Data pengamatan jumlah daun. Sidik ragam menunjukkan bahwa pemberian pupuk Mikrobat (C) dengan berat umbi berbeda (B) memberikan pengaruh sangat nyata. Sedangkan interaksinya tidak berpengaruh nyata terhadap jumlah daun.

Tabel 3. Rata-Rata Jumlah Daun (cm) pada Pemberian Pupuk Mikrobat dengan Berat Umbi Berbeda terhadap Pertumbuhan dan Produksi Tanaman Bawang Merah pada umur 28 HST.

\begin{tabular}{|c|c|c|c|c|c|}
\hline \multirow{2}{*}{$\begin{array}{c}\text { Pupuk } \\
\text { Mikrobat }\end{array}$} & \multicolumn{3}{|c|}{ Berat Umbi } & \multirow{2}{*}{$\begin{array}{l}\text { Rata- } \\
\text { Rata }\end{array}$} & \multirow{2}{*}{$\begin{array}{r}\text { BNT } \\
\text { Taraf } \\
\alpha \mathbf{0 , 0 1}\end{array}$} \\
\hline & B1 & B2 & B3 & & \\
\hline C0 & 19.83 & 20.33 & 20.83 & $20.33^{\mathrm{a}}$ & 0.42 \\
\hline C1 & 20.83 & 22.17 & 22.67 & $21.89^{\mathrm{a}}$ & \\
\hline $\mathrm{C2}$ & 21.17 & 22.50 & 23.67 & $22.44^{\mathrm{b}}$ & \\
\hline Rata-Rata & $20.61^{\mathrm{a}}$ & $21.67^{\mathrm{a}}$ & $22.39^{\mathrm{b}}$ & & \\
\hline $\begin{array}{l}\text { BNT } \\
\text { Taraf } \alpha \\
0,01\end{array}$ & 0.42 & & & & \\
\hline
\end{tabular}

Hasil Uji Beda Nyata Terkecil pada tara $\alpha 0,01$ pada Tabel 3. Memperlihatkan bahwa perlakuan pupuk Mikrobat dengan dosis $20 \mathrm{ml} /$ liter air (C2) berpengarauh lebih baik dan berbeda sangat nyata dibandingkan dengan perlakuan yang lain. Demikian juga dengan berat umbi \pm 10 gram (B3) memperlihatkan jumlah daun terbaik dan berbeda sangat nyata dibandingkan dengan perlakuan yang lain.

Data pengamatan jumlah daun, sidik ragam menunjukkan bahwa pemberian pupuk Mikrobat (C) dengan berat umbi berbeda (B) memberikan pengaruh sagat nyata. Sedangkan interaksinya tidak berpengaruh nyata terhadap jumlah daun.

Tabel 4. Rata-Rata Jumlah Daun (cm) pada Pemberian Pupuk Mikrobat dengan Berat Umbi Berbeda terhadap Pertumbuhan dan Produksi Tanaman Bawang Merah pada umur 56 HST.

\begin{tabular}{|c|c|c|c|c|c|}
\hline \multirow{2}{*}{$\begin{array}{l}\text { Pupuk } \\
\text { Mikrobat }\end{array}$} & \multicolumn{3}{|c|}{ Berat Umbi } & \multirow{2}{*}{$\begin{array}{l}\text { Rata- } \\
\text { Rata }\end{array}$} & \multirow{2}{*}{$\begin{array}{c}\text { BNT } \\
\text { Taraf } \\
\alpha \quad 0,01\end{array}$} \\
\hline & B1 & B2 & B3 & & \\
\hline $\mathrm{CO}$ & 25.17 & 25.83 & 26.83 & $25.94^{\mathrm{a}}$ & 0.53 \\
\hline C1 & 26.83 & 22.96 & 24.13 & $24.64^{\mathrm{a}}$ & \\
\hline $\mathrm{C} 2$ & 27.33 & 29.33 & 31.17 & $29.28^{\mathrm{b}}$ & \\
\hline Rata-Rata & $26.44^{\mathrm{a}}$ & $26.04^{\mathrm{a}}$ & $27.38^{\mathrm{b}}$ & & \\
\hline $\begin{array}{l}\text { BNT Taraf } \\
\alpha 0,01\end{array}$ & 0.53 & & & & \\
\hline
\end{tabular}

Hasil Uji Beda Nyata Terkecil pada tara $\alpha 0,01$ pada Tabel 4. Memperlihatkan bahwa perlakuan pupuk Mikrobat dengan dosis $20 \mathrm{ml} /$ liter air (C2) berpengarauh lebih baik dan berbeda sangat nyata dibandingkan dengan perlakuan yang lain. Demikian juga dengan berat umbi \pm 10 gram (B3) memperlihatkan jumlah daun terbaik dan berbeda sangat nyata dibandingkan dengan perlakuan yang lain.

Data hasil pengamatan jumlah daun tanaman bawang merah diumur 14 dan 24 HST dan sidik ragamnya disajikan pada tabel lampiran 5.a 5.b dan 7.a 7.b dan Sidik ragam menunjukkan bahwa pemberian pupuk Mikrobat (C) memberikan pengaruh sagat nyata diumur 14 dan 42 HST. Demikian juga dengan berat umbi yang berbeda (B) memberikan pengaruh sagat 
nyata diumur 14 dan 42 HST. Sedangkan interaksinya memperlihatkan pegaruh sangat nyata diumur 14 HST namun tidak berbeda nyata pada umur 42 HST.

Tabel 5. Rata-Rata Jumlah Daun (helai) pada Pemberian Pupuk Mikrobat dengan Berat Umbi Berbeda terhadap Pertumbuhan dan Produksi Tanaman Bawang Merah pada umur 14 dan 42 HST.

\begin{tabular}{|c|c|c|}
\hline \multirow{2}{*}{ Perlakuan } & \multicolumn{2}{|c|}{ Jumlah Daun (Helai) } \\
\hline & 14 HST & $42 \mathrm{HST}$ \\
\hline C0B1 & $5,83^{\mathrm{a}}$ & $29,83^{\mathrm{a}}$ \\
\hline C0B2 & $6,17^{\mathrm{a}}$ & $30,50^{\mathrm{a}}$ \\
\hline C0B3 & $6,83^{\mathrm{a}}$ & $31,50^{\mathrm{a}}$ \\
\hline C1B1 & $8,00^{\mathrm{c}}$ & $31,50^{\mathrm{c}}$ \\
\hline C1B2 & $7,67^{\mathrm{a}}$ & $33,17^{\mathrm{a}}$ \\
\hline C1B3 & $9,50^{\mathrm{c}}$ & $34,50^{\mathrm{a}}$ \\
\hline C2B1 & $9,83^{\mathrm{c}}$ & $32,00^{\mathrm{a}}$ \\
\hline $\mathrm{C} 2 \mathrm{~B} 2$ & $8,83^{\mathrm{c}}$ & $34,00^{\mathrm{c}}$ \\
\hline C2B3 & $11,17^{\mathbf{b}}$ & $36,33^{\mathbf{b}}$ \\
\hline & $0,51^{*}$ & $0,48 *$ \\
\hline BNT & Taraf $\alpha \mathbf{0 , 0 1}$ & Taraf $\alpha \mathbf{0 , 0 5}$ \\
\hline Keterangan : $\mathrm{Al}$ & $\begin{array}{l}\text { kka yang diikut } \\
\text { la kolom menu } \\
\text { la BNT Taraf } \\
\text { ak nyata; *: nya }\end{array}$ & $\begin{array}{l}\text { huruf yang tidak sama } \\
\text { berbeda sangat nyata } \\
\text { dan Taraf } \alpha 0,05 \text {; tn: } \\
\text { angat nyata. }\end{array}$ \\
\hline
\end{tabular}

Hasil Uji Beda Nyata Terkecil pada taraf $\alpha 0,01$ dan taraf $\alpha 0,05$ pada Tabel 5. Memperlihatkan bahwa perlakuan pupuk Mikrobat dengan dosis $20 \mathrm{ml} /$ liter air dengan berat umbi \pm 10 gram (C2B3) memperlihatkan rata-rata jumlah daun terbaik dan berbeda nyata dengan perlakuan lainnya pada umur 14 HST, dan juga pada umur 42 HST memperlihatkan bahwa perlakuan pupuk Mikrobat dengan dosis $20 \mathrm{ml} /$ liter air dengan berat umbi \pm 10 gram $(\mathrm{C} 2 \mathrm{~B} 3)$ memperlihatkan rata-rata jumlah daun terbaik dan berbeda nyata dengan perlakuan lainnya.

\section{Jumlah Anakan}

Data pengamatan jumlah anakan dan sidik ragam disajikan pada tabel lampiran 9a. dan 9b. Sidik ragam menunjukkan bahwa pemberian pupuk Mikrobat (C) dengan berat umbi berbeda (B) memberikan pengaruh sagat nyata. Sedangkan interaksinya tidak berpengaruh nyata terhadap jumlah anakan.

Tabel 6. Rata-Rata Jumlah Anakan (umbi) pada Respon Pemberian pupuk Mikrobat dengan Berat Umbi Berbeda terhadap Pertumbuhan dan Produksi Tanaman Bawang Merah (Alium ascalonicum $\mathrm{L}$ ).

\begin{tabular}{|c|c|c|c|c|c|}
\hline \multirow{2}{*}{$\begin{array}{c}\text { Pupuk } \\
\text { Mikrobat }\end{array}$} & \multicolumn{3}{|c|}{ Berat Umbi } & \multirow{2}{*}{$\begin{array}{l}\text { Rata- } \\
\text { Rata }\end{array}$} & \multirow{2}{*}{$\begin{array}{c}\text { BNT } \\
\text { Taraf } \\
\alpha 0,01\end{array}$} \\
\hline & B1 & B2 & B3 & & \\
\hline $\mathrm{CO}$ & 5,00 & 5,50 & 5,50 & $5,33^{a}$ & 0,42 \\
\hline $\mathrm{C} 1$ & 5,67 & 6,00 & 6,17 & $5,59^{\mathrm{a}}$ & \\
\hline $\mathrm{C} 2$ & 6,17 & 6,50 & 6,83 & $6,50^{\mathrm{b}}$ & \\
\hline Rata-Rata & $5,61^{\mathrm{a}}$ & $11,65^{\mathrm{a}}$ & $12,15^{\mathrm{b}}$ & & \\
\hline $\begin{array}{l}\text { BNT } \\
\text { Tarafo0,01 }\end{array}$ & 0,42 & & & & \\
\hline
\end{tabular}

Hasil Uji Beda Nyata Terkecil pada tara $\alpha 0,01$ pada Tabel 3. Memperlihatkan bahwa perlakuan pupuk Mikrobat dengan dosis $20 \mathrm{ml} /$ liter air (C2) berpengarauh lebih baik dan berbeda sangat nyata dibandingkan dengan perlakuan yang lain. Demikian juga dengan berat umbi \pm 10 gram (B3) memperlihatkan jumlah anakan terbaik dan berbeda sangat nyata dibandingkan dengan perlakuan yang lain.

\section{Berat Segar}

Data pengamatan berat segar, sidik ragam menunjukkan bahwa pemberian pupuk Mikrobat (C) dengan berat umbi berbeda (B) memberikan pengaruh sagat nyata. Sedangkan interaksinya tidak berpengaruh nyata terhadap berat segar.

Tabel 7. Diagram Batang Rata-Rata Berat Segar (gram) pada Respon Pemberian pupuk Mikrobat dengan Berat Umbi Berbeda terhadap Pertumbuhan dan Produksi Tanaman Bawang Merah (Alium ascalonicum L).

\begin{tabular}{|c|c|c|c|c|c|}
\hline \multirow{2}{*}{$\begin{array}{l}\text { Pupuk } \\
\text { Mikrobat }\end{array}$} & \multicolumn{3}{|c|}{ Berat Umbi } & \multirow{2}{*}{$\begin{array}{l}\text { Rata- } \\
\text { Rata }\end{array}$} & \multirow{2}{*}{$\begin{array}{r}\text { BNT } \\
\text { Taraf } \\
\alpha 0,01 \\
\end{array}$} \\
\hline & B1 & B2 & B3 & & \\
\hline $\mathrm{CO}$ & 70,17 & 70,50 & 72,83 & $71,17^{\mathrm{a}}$ & 0,27 \\
\hline C1 & 72,17 & 72,83 & 75,33 & $73,44^{\mathrm{a}}$ & \\
\hline $\mathrm{C2}$ & 73,33 & 74,33 & 77,50 & $75,06^{\mathbf{b}}$ & \\
\hline Rata-Rata & $71,89^{\mathrm{a}}$ & $72,56^{\mathrm{a}}$ & $75,22^{b}$ & & \\
\hline $\begin{array}{l}\text { BNT } \\
\text { Taraf } \alpha \\
0,01\end{array}$ & 0,27 & & & & \\
\hline
\end{tabular}

Hasil Uji Beda Nyata Terkecil pada tara $\alpha 0,01$ pada Tabel 7. Memperlihatkan bahwa perlakuan pupuk Mikrobat dengan dosis $20 \mathrm{ml} /$ liter air (C2) berpengarauh lebih baik dan berbeda sangat nyata dibandingkan dengan perlakuan yang lain. Demikian juga dengan berat umbi \pm 10 gram (B3) memperlihatkan berat segar terbaik dan berbeda sangat nyata dibandingkan dengan perlakuan yang lain.

\section{Berat Kering}

Data pengamatan berat kering, sidik ragam menunjukkan bahwa pemberian pupuk Mikrobat (C) dengan berat umbi berbeda (B) memberikan pengaruh sagat nyata. Sedangkan interaksinya tidak berpengaruh nyata terhadap berat kering tanaman.

Tabel 8. Rata-Rata Berat kering (gram) pada Respon Pemberian pupuk Mikrobat dengan Berat Umbi Berbeda terhadap Pertumbuhan dan Produksi Tanaman Bawang Merah (Alium ascalonicum L)

\begin{tabular}{|c|c|c|c|c|c|}
\hline \multirow{2}{*}{$\begin{array}{l}\text { Pupuk } \\
\text { Mikrobat }\end{array}$} & \multicolumn{3}{|c|}{ Berat Umbi } & \multirow{2}{*}{$\begin{array}{l}\text { Rata- } \\
\text { Rata }\end{array}$} & \multirow{2}{*}{$\begin{array}{r}\text { BNT } \\
\text { Taraf } \\
\alpha 0,01\end{array}$} \\
\hline & B1 & B2 & B3 & & \\
\hline $\mathrm{CO}$ & 29,00 & 29,33 & 30,17 & $29,50^{\mathrm{a}}$ & 0,43 \\
\hline $\mathrm{C} 1$ & 30,83 & 31,00 & 32,00 & $31,28^{\mathbf{a}}$ & \\
\hline $\mathrm{C2}$ & 30,67 & 32,50 & 33,17 & $32,11^{\mathbf{b}}$ & \\
\hline Rata-Rata & $30,17^{\mathrm{a}}$ & $30,94^{\mathrm{a}}$ & $31,78^{\mathrm{b}}$ & & \\
\hline $\begin{array}{c}\text { BNT Taraf } \\
\alpha \quad 0,01 \\
\end{array}$ & 0,43 & & & & \\
\hline
\end{tabular}

Hasil Uji Beda Nyata Terkecil pada tara $\alpha 0,01$ pada Tabel 8. Memperlihatkan bahwa perlakuan pupuk Mikrobat dengan dosis $20 \mathrm{ml} /$ liter air (C2) berpengarauh lebih baik dan berbeda sangat nyata dibandingkan 
dengan perlakuan yang lain. Demikian juga dengan berat umbi \pm 10 gram (B3) memperlihatkan berat kering terbaik dan berbeda sangat nyata dibandingkan dengan perlakuan yang lain.

\section{Kesimpulan}

Dari hasil penelitian yang dilakukan dapat disimpulkan sebagai berikut :

1. Pemberian pupuk Mikrobat dengan dosis $20 \mathrm{~lm} /$ liter air (C2) memberikan pengaruh baik terhadap parameter panjang daun, jumlah daun, jumlah anakan, berat segar dan berat kering tanaman bawang merah.

2. Penanaman berat umbi \pm 10 gram (B3) berpengaruh lebih baik pada jumlah daun, jumlah anakan, berat segar dan berat kering tanaman bawang merah.

3. Interaksi antara pupuk Mikrobat dengan dosis 20 $\mathrm{lm} /$ liter air dengan berat umbi \pm 6 gram (C2B1) memberikan pengaruh baik pada parameter panjang daun pada umur 28, 42 dan 56 HST dan juga jumlah daun pada umur 14 dan 42 HST.

\section{Saran}

Berdasarkan hasil penelitian maka penulis menyarankan menggunaan pupuk Mikrobat dengan dosis $20 \mathrm{ml} /$ liter air, begitupun juga dengan berat umbi \pm 10 gram untuk budidaya tanaman bawang merah.

\section{Daftar Pustaka}

Ashrafida, R. 2013. Pertumbuhan dan Produksi Bawang Merah (Allium ascalonicum L.) dengan Pemberian Pupuk Kandang Ayam dan EM4 (Effective Microorganisms4).Fakultas Pertanian USU. Medan.

Anas, I., dan M. E. Premono. 2010. Mikroorganisme Tanah Pelarut Fosfat dan Peranannya Dalam Pertanian. DalamKongres Nasional Himpunan Ilmu Tanah Indonesia.

Azmi, 2011. Pengaruh Varietas dan Ukuran Umbi terhadap Produktivitas Bawang Merah. J. Hort. 21(3):206-213, 2011

Ciptady, M. A. 2015. Budidaya Bawang Merah. http://cybex.pertanian. go.Id/gerbangdaerah/detail/9371/budidayabawang merah/ (Dia kses pada tanggal 16 Oktober 2015).

Cahyono. B. 2010. Bawang Merah Teknik Budidaya dan Analisis Usaha Tani. Penerbit Kanisius. Yogyakarta.

Damanik,., 2011. Kesuburan Tanah dan Pemupukan. UsuPress. Medan.

Elfiati, D. 2011. Peranan Mikroba Pelarut Fosfat Terhadap Pertumbuhan Tanaman. Universitas Sumatra Utara
Hamzah, 2013. Efektivitas Pupuk Hayati Petrobio dan Pupuk Phonska Terhadap Pertumbuhan dan Produksi Tanaman Jagung. Sekolah Tinggi Penyuluhan Pertanian (STPP). Gowa.

Hervani, D.L., Syukriani., E. Swasti dan Erbasrida. 2010. Teknologi budidaya bawang merah pada beberapa media dalam pot di Kota Padang. Jurnal Warta Pengabdian Andalas, 15(22): 18.

Haryono Ludi. 2009. Studi kompertif pendapatan dan keuntungan antara petani pasca panen dan petani tanpa pasca panen pada tanaman bawang merah di Desa Banjar Anyar Kecamatan Brebes Kabupaten Brebes. Skripsi. FP. UMY

Jedeng, I.W. 2011. Pengaruh jenis dan dosis pupuk organik terhadap pertumbuhan dan hasil ubi Jalar (Ipomoea batatas (L.) Lamb.) Var. lokal ungu. Tesis. Program Pasca Sarjana. Universitas Udayana. Denpasar.

Lana, W. 2010. Pengaruh Dosis Pupuk Kandang Sapi dan Berat Benih Terhadap Pertumbuhan dan Hasil Tanaman Bawang Merah (Alliumascalonicum L). J. Ganec Swara, 86.

Lakitan, B. 2010. Fisiologi Pertumbuhan dan Perkembangan Tanaman. PT RajaGrafindo Persada. Jakarta.

Meirina, T., S. Darmanti, dan S. Haryanti. 2010. Produktivitas kedelai (Glycine max (L.) Merril var. Lokon) yang diperlakukan dengan pupuk organik cair lengkap pada dosis dan waktu pemupukan yang berbeda. Skripsi. Universitas Diponegoro.

Melissa Syamsiah Respon Perkembangan Akar Tanaman Kedelai (Glycine Max. (L.) Merril) Terhadap Pemberian Pupuk Mikrobat. Jurnal Agroekoteknologi . E-ISSN No. 2337- 6597 Vol.4. No.3, Juni 2016. (614) :2167 - 2172

Nugrahini, Tutik. 2013. Respon Tanaman Bawang Merah (Allium Ascolonicum L.) Varietas Tuk Tuk Terhadap Pengaturan Jarak Tanam Dan Konsentrasi Pupuk Organik Cair Nasa. Fakultas Pertanian Universitas Widya Gama Mahakam. Samarinda

Pulok et. al., (2014) dalam YATI Nurlaeni Dan Muhammad Imam Surya (2015) "Respon stek pucuk Camelia japonica terhadap pemberian Zat Pengatur Tumbuh organik" journal Pros Sem Nas Masy Biodiv Indon Volume 1, Nomor 5, Halaman: 1211-1215

Richard Gunawan. 2011. Produksi Masal Inokulum Azotobacter, Azospirillum dan Bakteri Pelarut Fosfat dengan Menggunakan Media Alternatif.

Rizqie Lestya Ningsih et al., 2014. Bakteri Pendegradasi Selulosa dari Serasah Daun Avicennia alba Blume di Kawasan Hutan Mangrove Peniti Kabupaten Pontianak. Jurnal Protobiont. Vol 3 (1): $34-40$ 
Samad, S. (2010). Respon Pupuk Kandang Sapi dan KCL Terhadap Pertumbuhan dan Produksi Bawang Merah Alium ascalanicum L, Buletin Penelitian. Lembaga Penelitian Universitas Hasanuddin

Sufyati, Y. 2011. Pengaruh Ukuran Fisik Dan Jumlah Umbi Per Lubang Terhadap Pertumbuhan Dan Hasil Bawang Merah (Allium ascalonicum L.). Jurnal Floratek, 2(1). pp.43-54.

Sumiati, E., Hidayat. 2009. Perbaikan Teknologi Produksi Umbi Benih Bawang Merah Dengan Ukuran Umbi Benih,Aplikasi Zat Pengatur Tumbuh, Dan Unsur Hara Mikroelemen. Jurnal Hortikultura, 14(1). pp.1-2.

Sumarni, N. dan A. Hidayat 2009. Balai Penelitian Tanaman Sayuran Pusat Penelitian dan Pengembangan Hortikultura Badan Penelitian dan Pengembangan Pertanian. Panduan Teknis PTT Bawang Merah No.3, Tahun 2005. ISBN : 979-8304-49-7. Bandung: 22 hal.

Sutono, et. al., 2012. Penerapan Teknologi Pengelolaan Air dan Hara Terpadu untuk Bawang Merah di Donggala. Balai Penelitian Tanah. Badan Penelitian dan Pengembangan Pertanian. Departemen Pertanian. $41 \mathrm{Hlm}$

Sudirja, 2010. Pedoman bertanam bawang merah. Kanisius, Yogyakarta.

Sartono. 2009. Bawang Merah, Bawang Putih, Bawang Bombay. Intimedia Ciptanusantara. Jakarta Timur. 57 hal.

Suriana, N. 2011. Bawang Bawa Untung Budidaya Bawang Merah dan Bawang Putih. Cahaya Atma Pustaka. Yogyakarta. 104 hal.

Sumarwoto dkk. 2012. Aplikasi Pupuk Kalium dan N Balanser pada Budidaya Bawang Merah ( Allium ascalonicum L.) di Lahan Pasir Pantai. Fakultas Pertanian. UPN.

Sutedjo, M.M., 2009, Pupuk dan Pemupukan, Jakarta : Rineka Cipta.

Samadi, B. dan B. Cahyono. 2012. Intensifikasi Budidaya Bawang Merah. Kanisius. Yogyakarta. 74 hal.

Semangun H. 2010. Penyakit-penyakit Tanaman Hotikultura di Indonesia. Yogyakarta: Gadjah Mada Univesity Press.

Tim Bina Karya Tani. 2011. Pedoman Bertanam Bawang Merah. Yrama Widya, Bandung. 120 hal.

Tjitrosoepomo, gembong. 2012. Taksonomi Tumbuhan Spermatophyta. Yogyakarta: Gajah Mada University press.

Taufiq Bachtiar Dkk 2017. Pengaruh Formula Pupuk Mikrobat Terhadap Kadar N-Total, Serapan P, Dan Pertumbuhan Tanaman Jagung. Website: jurnal. Uml.ac.id/indekx.php/semnastan

Wibowo, 2010. Budidaya Bawang Putih, Bawang Merah, Bawang Bombay. Penebar Swadaya. Jakarta. 194 hal. 